\title{
ANALISIS SISTEM MONITORING KEAMANAN SERVER DENGAN SMS ALERT BERBASIS SNORT
}

\author{
I Komang Krisna Ade Marta1, I Nyoman Buda Hartawan2, I Kadek Susila Satwika3
}

1 Prodi Sistem Komputer STIMIK STIKOM INDONESIA, Jl. Tukad Pakerisan No.97, Panjer, Kec. Denpasar Sel., Kota Denpasar, Bali 80225 INDONESIA

2 Prodi Sistem Komputer STIMIK STIKOM INDONESIA, Jl. Tukad Pakerisan No.97, Panjer, Kec. Denpasar Sel., Kota Denpasar, Bali 80225 INDONESIA

3 Prodi Sistem Komputer STIMIK STIKOM INDONESIA, Jl. Tukad Pakerisan No.97, Panjer, Kec. Denpasar Sel., Kota Denpasar, Bali 80225 INDONESIA

\begin{abstract}
Abstrak
Keamanan server merupakan hal penting yang perlu diberikan perhatian lebih saat melakukan konfigurasi server. Pada umumnya serangan yang terjadi pada server diketahui setelah terjadinya kegagalan pada server dalam memberikan layanan. Pada penelitian ini, dibangun sebuah sistem keamanan server yang dapat melakukan monitoring pada sebuah server ketika terdeteksi adanya aktivitas yang tidak wajar. Pemberitahuan akan dikirimkan melalui SMS (Short Message Service) ke handphone Administrator jaringan. Sistem yang dibangun melakukan pendeteksian intrusi pada server secara realtime menggunakan SNORT. Ketika terjadi akses yang tidak wajar pada server, maka SNORT akan mendeteksi dan mengirimkan informasi terjadinya aktivitas yang tidak wajar ke Administrator jaringan. Sistem ini diujikan dengan lima jenis serangan yakni PING Attack, DoS/DDoS Attack, Port Scanning, Telnet Access dan FTP Access. Parameter yang diamati pada penelitian ini adalah beban aktivitas yang terjadi pada sumber daya server meliputi CPU, Memory (RAM) dan beban jaringan. Hasil penelitian menunjukkan bahwa saat terjadi upaya serangan terhadap server, SNORT dapat menghasilkan alert yang akan disimpan pada log sekaligus dikirimkan ke handphone Administrator melalui SMS.
\end{abstract}

Kata Kunci:

Keamanan Server, Monitoring Server, IDS, SNORT, SMS Gateway.

\begin{abstract}
Server security is an important thing that needs to be given more attention when configuring a server. In general, attacks that occur on the server are known after a failure on the server in providing services. In this study, a server security system was built that could monitor a server when an unusual activity was detected. Notifications will be sent via SMS (Short Message Service) to the network Administrator's smartphone. The system is built to detect intrusions on the server in real time using SNORT. When improper access occurs on the server, SNORT will detect and send information about the occurrence of unusual activity to the network Administrator. This system is tested with five types of attacks namely PING Attack, DoS / DDoS Attack, Port Scanning, Telnet Access and FTP Access. The parameters observed in this study are the activity load that occurs on server resources including CPU, Memory (RAM) and network load. The results showed that when an attempt was made to attack the server, SNORT could produce alerts that would be stored in a log as well as sent to the Administrator's smartphone via SMS.
\end{abstract}

Keywords:

Server Security, Server Monitoring, IDS, SNORT, SMS Gateway.

\footnotetext{
*Korespondensi

E-mail: krisnaademarta@yahoo.co.id, buda.hartawan@gmail.com,susila.satwika@gmail.com
} 


\section{PENDAHULUAN}

Seiring dengan berkembangnya teknologi informasi, jaringan komputer dan server sudah umum digunakan dalam sebuah institusi baik itu di sebuah perusahaan, pemerintahan, organisasi dan lain sebagainya. Pemanfaatan teknologi saat ini khususnya dibidang pendidikan memungkinkan untuk melaksanakan kegiatan pembelajaran melalui jarak jauh. Praktikuam adalah salah satu kegiatan pembelajaran yang umumnya dilakukan secara tatap muka di ruang laboratorium. Namun, pemanfaatan server memungkinkan kegiatan laboratorium khusunya tentang bidang teknologi informasi melalui laboratorium virtual(Hartawan \& Satwika, 2016). Server adalah komputer yang memberikan layanan kepada klien sehingga perlu dilengkapi dengan spesifikasi yang tinggi dan media penyimpanan yang besar (Hartawan \& Iswara, 2015). Namun selain itu semakin berkembangnya penggunaan server yang ada saat ini, faktor keamanan/security merupakan faktor vital dan perlu diperhitungkan secara serius. Keamanan server yang dimaksud dapat berupa upaya memonitoring dan mencegah penggunaan server yang tidak sah ataupun serangan dari pihak eksternal maupun internal. Tujuannya yaitu untuk mencegah terjadinya kerusakan yang fatal pada layanan server apabila terjadi serangan. Saat ini perkembangan teknologi memungkinkan perangkat elektronik dikontrol melalui jaringan internet (Hartawan \& Sudiarsa, 2019). Perangkat-perangkat elektronik saat ini sudah mulai diintegrasikan dengan aplikasi teknologi komputer (Ekayana, Hartawan, Desnanjaya, \& Joni, 2020)(Desnanjaya, Iswara, Ekayana, Santika, \& Hartawan, 2020). Hal ini juga dapat menimbulkan potensi terjadinya serangan, yang menyebabkan alih kendali terhadap perangkat elektronik yang digunakan.

Metode yang paling umum digunakan untuk mengamankan sebuah server adalah dengan menggunakan firewall. Sistem keamanan firewall tidaklah cukup untuk meminimalkan dampak serangan yang terjadi pada server. Pada umumnya serangan yang terjadi pada server diketahui setelah terjadinya kegagalan server dalam memberikan layanan. Administrator membutuhkan waktu yang cukup lama untuk menganalisa kerusakan dan proses pemulihan terhadap server tersebut. Hal ini tentu sangat merugikan baik pihak Administrator maupun pengguna server itu sendiri.

Oleh karena itu, untuk mengatasi permasalahan diatas, perlu dibangun sebuah sistem keamanan Server yang dapat memonitoring aktivitas sebuah Server ketika terdeteksi aktivitas yang tidak wajar dengan mengirimkan notifikasi melalui SMS (Short Message Service) ke handphone Administrator jaringan secara realtime. Dengan kata lain Administrator dapat langsung menerima pemberitahuan bahwa sedang terjadi serangan/aktifitas yang tidak wajar pada server tersebut, sehingga dapat langsung mengambil tindakan secepatnya, seperti dengan mengendalikan server secara jarak jauh untuk mencegah penyerangan yang berakibat lebih buruk terhadap kondisi kestabilan dan keamanan server.

Pada penelitian ini dibuat rancang bangun sistem monitoring keamanan server dengan SMS alert berbasis SNORT. Sistem ini mampu mengirimkan pemberitahuan melalui SMS Gateway. Sistem ini diujikan dengan lima jenis serangan yakni PING Attack, DoS/DDoS Attack, Port Scanning, Telnet Access dan FTP Access. Parameter yang diamati pada penelitian ini adapa CPU, Memory (RAM) dan beban jaringan.

\section{METODE}

Snort merupakan bagian dari IDS dan merupakan sebuah perangkat lunak open soure. Snort mampu melakukan analisa realtime traffic dan packet logger pada jaringan IP dan dapat menganalisa protocol dan melakukan pendeteksian variasi penyerangan. Snort juga memiliki kemampuan realtime alert, dimana mekanisme pemaksukan alert dapat berupa user syslog, file, uni socket ataupun melalui Server (Rehman, 2003). Dalam mengoprasikan snort mempunyai tiga buah mode, yaitu:

\section{A. Sniffer Mode}

Sniffer Mode ini berfungsi untuk melihat paket yang lewat di jaringan, maka untuk menjalankan snort pada sniffer mode tidak terlalu susah.

\section{B. Packet logger mode}

Packet logger mode berfungsi untuk mencatat semua paket yang lewat dijaringan yang kemudian akan dianalisa. Bahkan dapat menyimpan paket dalam disk. Sehingga perlu diinisialisasikan terlebih dahulu logging direktorinya pada file configurasi snort.

\section{Network Intrusion Detection System (NIDS) mode}

Dengan menggunakan network Intrusion Detection System (NIDS) tidak diperlukan lagi untuk menyimpan seluruh paket yang datang pada sebuah jaringan. karena pada mode ini data yang disimpan 
atau ditampilkan adalah paket - paket yang berbahaya dengan cara mengkonfigurasi snort.conf terlebih dahulu.

\section{SMS GATEWAY}

SMS Gateway adalah sebuah perangkat yang menawarkan layanan transit SMS, mentransfor-masikan pesan ke jaringan selular dari media lain, atau sebaliknya, sehingga memungkinkan pengiriman atau penerimaan pesan SMS dengan atau tanpa menggunakan ponsel (Tarigan, 2012).

Pada hakekatnya SMS Gateway sama dengan ketika kita menggunakan handphone seperti biasa. Hanya saja pada beberapa aplikasi sms gateway yang telah dikembangkan, ada perbedaan untuk interface-nya. Bila menggunakan handphone maka interface-nya berupa keypad dan layar handphone tersebut, sedangkan bila menggunakan sms gateway maka interface-nya keyboard komputer dan layar monitor. Selain interface, ada perbedaan pula pada cara kerjanya. Pada beberapa aplikasi ada fitur autoreply. Fitur ini memungkinkan sistem tersebut membalas otomatis sms dari user secara langsung.

Sebagaimana penjelasan diatas, SMS Gateway dapat terhubung ke media lain seperti perangkat SMSC dan Server milik Content Provider melalui link IP untuk memproses suatu layanan SMS.

\section{BARNYARD DAN BASE (BASIC ANALYSIS AND SECURITY ENGINE)}

Barnyard2 adalah tool open source sebagai penerjemah alert unified dan log dari Snort. Barnyard2 dapat meningkatkan efisiensi Snort dengan cara mengurangi beban pada sensor deteksi. Barnyard2 bekerja dengan membaca Snort's unified logging output files dan memasukannya kedalam database (Tarigan, 2012). Jika database tidak tersedia maka Barnyard2 akan memasukan semua data ketika database tersedia kembali sehingga tidak ada alert atau log yang hilang. Sedangkan, Base adalah sebuah interface web untuk melakukan analisis dari intrusi yang snort telah deteksi pada jaringan. BASE ditulis oleh kevin johnson adalah program analisis sitem jaringan berbasis PHP yang mencari dan memproses database dari security event yang dihasilkan oleh berbagai program monitoring jaringan, firewall, atau sensor IDS.

\section{LOIC (LOW ORBIT ION CANNON)}

LOIC Adalah Low Orbit Ion Cannon atau bisa disebut LOIC berfungsi untuk melumpuhkan server sebuah situs website. ini adalah software DDOS yang paling ampuh, terbukti komunitas hacker sekelas 'Anonymous' menggunakan tool loic ini untuk melancarkan aksinya. Software Loic ini juga pernah melumpuhkan server facebook yang memiliki 60 server yang tersebar luas di seluruh dunia walau hanya beberapa menit (Tarigan, 2012).

\section{METODE}

\section{A. Teknik Pengumpulan Data}

Dalam penelitian ini, penulis menggunakan teknik pengumpulan data sekunder. Data Sekunder adalah studi yang mempelajari, meneliti, dan mencari berbagai sumber dari buku-buku, jurnal ilmiah, situs-situs resmi di internet serta bacaan-bacaan yang berkaitan dengan penelitian ini. Penulis mempelajari hal-hal yang berkaitan dengan jaringan komputer, Server, keamanan jaringan dan Server, firewall, IDS, Snort, SMS Gateway dan lain sebagainya.

\section{B. Analisis Kebutuhan Data}

Adapun analisis kebutuhan sistem fungsional dari sistem monitoring kemanaan Server dengan pemberitahuan melalui SMS berbasis Snort yaitu:

1. Sistem dapat bekerja sesuai dengan rule keamanan yang ditentukan.

2. Sistem dapat menyimpan data serangan kedalam File Alert Database

3. Sistem dapat mengirim pemberitahuan serangan melalui SMS ke Handphone Administrator.

Adapun analisis kebutuhan sistem non-fungsional dari sistem monitoring kemanaan Server dengan pemberitahuan melalui SMS ini terdiri dari Kebutuhan Hardware dan Kebutuhan Software. 


\section{a. Kebutuhan Hardware}

Berikut perangkat keras (Hardware) yang penulis gunakan dalam membangun sistem monitoring kemanaan Server dengan pemberitahuan melalui SMS berbasis SNORT:

Tabel 1. Daftar Kebutuhan Hardware

\begin{tabular}{crc}
\hline No & \multicolumn{1}{c}{ Nama } & Jumlah \\
\hline 1 & Server & 1 \\
2 & PC Attacker & 1 \\
3 & Kabel LAN & 1 \\
4 & Switch & 1 \\
5 & Modem & 1 \\
6 & Handphone & 1 \\
\hline
\end{tabular}

\section{b. Kebutuhan Software}

Berikut perangkat keras (Hardware) yang penulis gunakan dalam membangun sistem monitoring kemanaan Server dengan pemberitahuan melalui SMS berbasis Snort:

Tabel 2. Daftar Kebutuhan Software

\begin{tabular}{cl}
\hline No & \multicolumn{1}{c}{ Nama } \\
\hline 1 & Sistem Operasi Linux Ubuntu 14.04 LTS \\
2 & Command Line \\
3 & SNORT 2.9 \\
4 & Banyard2 dan BASE \\
5 & LAMP \\
6 & GAMMU \\
7 & Sistem Operasi Windows 10 Professional-64 Bit \\
8 & LOIC \\
9 & Zmap-Zenmap \\
\hline
\end{tabular}

\section{Topologi Jaringan}

Setelah memahami flowchart (alur kerja) dari sistem monitoring kemanaan Server dengan pemberitahuan melalui SMS berbasis Snort, selanjutnya akan dijelaskan tentang Topologi Jaringan dari sistem ini. Pada Topologi Jaringan, Komputer Server dan Komputer Penyerang terhubung dengan media Kabel UTP dengan switch sebagai konsentratornya. Di Komputer Server terpasang Modem SMS Gateway dengan media USB. Modem SMS Gateway ini akan mengirimkan SMS Alert ke Handphone Administrator. Topologi jaringan ini meggunakan skema IP kelas C dengan network 172.16.1.0/24.

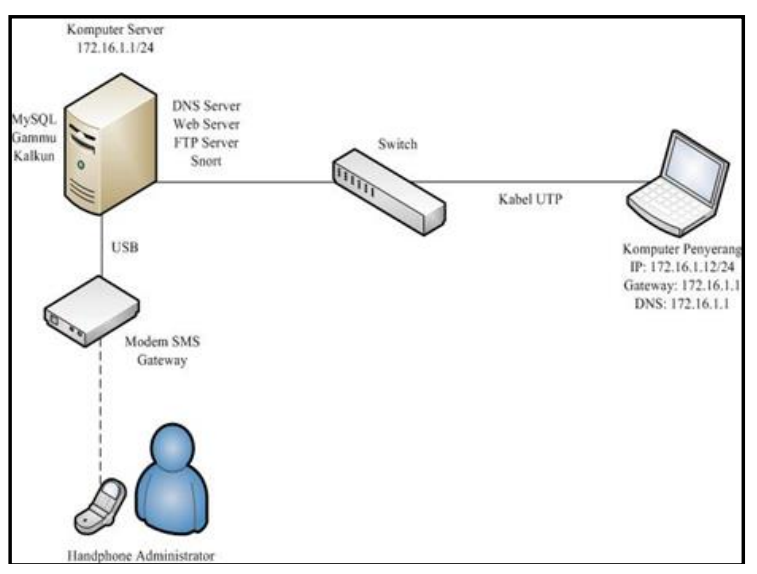

Gambar 1. Topologi Jaringan Sistem 


\section{Skenario Pengujian Sistem}

Pengujian dilakukan dengan cara melakukan berbagai macam serangan terhadap komputer server. Yang bertindak sebagai penyerang dalam skenario pengujian ini adalah komputer penyerang yang dengan media kabel LAN dan menggunakan penghubung switch. Serangan yang diujikan pada penelitian ini adalah PING Attack, DoS/DDoS Attack, Port Scanning, Telnet Access dan FTP Access. Pada setiap pengujian serangan, parameter Komputer Server yang berupa CPU, Memory dan Beban Jaringan akan di monitor untuk perbandingan sebelum serangan dan pada saat terjadi serangan.

\section{a. PING Attack (ICMP Flooding)}

PING Attack adalah penyerangan dengan mengeksploitasi system agar dapat membuat suatu target menjadi crash. Terjadinya system dikarenakan oleh pengiriman sejumlah paket yang besar bahkan sangat besar kearah target. Tidak semua perintah PING terhadap Komputer Server dapat dikatakan sebagai PING Attack, ada beberapa kondisi PING dimana Snort akan tetap mencatat alert tersebut namun tidak dikirimkan ke Handphone Administrator. Untuk lebih memahaminya dapat dilihat pada Tabel 3

Tabel 3. Protokol Kerja SMS Alert Terhadap PING Attack

\begin{tabular}{lrr}
\hline No & Nama & \multicolumn{2}{c}{ Alert Dikirim } \\
\hline 1 & PING normal 4 paket (ping 172.16.1.1) & Tidak \\
2 & PING terus menerus (ping 172.16.1.1 $-t$ ) & Tidak \\
3 & PING dengan lebih dari 10 paket dalam satu detik. & $Y a$ \\
\hline
\end{tabular}

Berdasarkan Tabel 3, SMS Alert hanya akan bekerja pada kondisi dimana terjadi PING dengan banyak paket lebih dari 10 dalam satu detik kepada Komputer Server. Hal ini dibuat untuk menghindari banyaknya SMS yang akan diterima oleh Administrator serta menimbulkan false alarm/ alarm yang salah.

\section{b. DoD/DdoS Attack}

Untuk pengujian DoS/DDoS Attack digunakan tool freeware LOIC (Low Orbit Ion Cannon), sama seperti PING Attack, ada beberapa kondisi DoS/DDoS dimana Snort akan tetap mencatat alert tersebut namun tidak dikirimkan ke Handphone Administrator. Untuk lebih memahaminya dapat dilihat pada Tabel 4.

Tabel 4. Protokol Kerja SMS Alert Terhadap DoS/DDoS Attack

\begin{tabular}{lrr}
\hline No & Kondisi & Alert Dikirim \\
\hline 1 & DoS/DDoS dengan jumlah thread dibawah 100 & Tidak \\
2 & DoS/DDoS dengan speed 'slower' & Tidak \\
3 & $\begin{array}{r}\text { DoS/DDoS dengan thread diatas 100, speed faster, } \\
\text { (jumlah paket DoS yang masuk }>1000 \text { dalam 3 detik) }\end{array}$ & $Y a$ \\
\hline
\end{tabular}

Berdasarkan Tabel 4, SMS Alert hanya akan bekerja pada kondisi dimana terjadi DoS/DDoS dengan banyak paket lebih dari 1000 dalam tiga detik kepada Komputer Server. Hal ini dibuat untuk menghindari banyaknya SMS yang akan diterima oleh Administrator serta menimbulkan false alarm / alarm yang salah.

\section{c. Port Scanning}

Untuk pengujian Port Scanning digunakan tool NMap-ZenMap. Untuk Port Scanning, setiap aksi dari Port Scanning selama bertujuan untuk memindai port TCP akan dikirimkan ke Handphone Administrator. Untuk lebih memahaminya dapat dilihat pada Tabel 5

Tabel 5. Protokol Kerja SMS Alert Terhadap Port Scanning

\begin{tabular}{lrr}
\hline No & Kondisi & Alert Dikirim \\
\hline 1 & Port Scanning UDP & Tidak \\
2 & Port Scanning TCP & $Y a$ \\
\hline
\end{tabular}


Berdasarkan Tabel 5, SMS Alert hanya akan bekerja pada kondisi dimana terjadi Port Scanning terhadap Port TCP.

\section{d. Telnet Access}

Untuk pengujian Telnet Akses tools yang digunakan adalah Command prompt yang tersedia pada Windows. Untuk Telnet Access, setiap aksi dari Telnet Access dikirimkan ke Handphone Administrator. Untuk lebih memahaminya dapat dilihat pada Tabel 6.

Tabel 6. Protokol Kerja SMS Alert Terhadap Telnet Akses

\begin{tabular}{lrr}
\hline No & Kondisi & Alert Dikirim \\
\hline 1 & $\begin{array}{r}\text { Telnet Akses terhadap Server } \\
\text { (telnet 172.16.1.1) }\end{array}$ & Ya \\
\hline
\end{tabular}

Berdasarkan Tabel 6, SMS Alert akan bekerja pada kondisi dimana terjadi Telnet Akses. Hal ini dikarenakan aktivitas Telnet hanya digunakan oleh Administrator jaringan sendiri. Apabila ada user yang mencoba untuk melakukan aktivitas Telnet maka akan ada SMS Alert.

\section{e. FTP Access}

Untuk pengujian FTP Akses tools yang digunakan adalah Command prompt yang tersedia pada Windows. Untuk FTP Access, apabila ada yang gagal untuk login ke FTP Server akan ada SMS Alert yang dikirimkan ke Handphone Administrator. Untuk lebih memahaminya dapat dilihat pada Tabel 7.

Tabel 7. Protokol Kerja SMS Alert Terhadap FTP Akses

\begin{tabular}{lrr}
\hline No & Kondisi & Alert Dikirim \\
\hline 1 & Login FTP Akses terhadap & Tidak \\
& Server berhasil & \\
2 & Login FTP Akses terhadap \\
Server gagal & $Y a$ \\
\hline
\end{tabular}

Berdasarkan Tabel 7, SMS Alert akan bekerja pada kondisi dimana ada yang gagal untuk login ke FTP.

\section{IMPLEMENTASI DAN PEMBAHASAN}

\section{A. Konfigurasi IP Address Jaringan}

Sebelum melakukan pengujian serangan terhadap sistem, perlu dilakukan persiapan terlebih dahulu. Persiapan pertama adalah konfigurasi IP Address pada masing-masing komputer agar dapat terhubung. Untuk Konfigurasi IP Address pada Komputer Server dapat dilihat pada Gambar 2

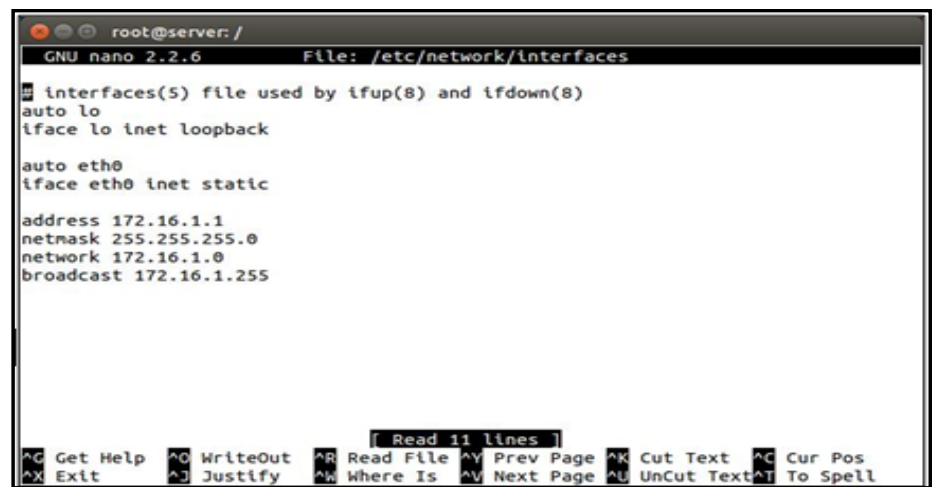

Gambar 2. IP Address Komputer Server

Untuk Konfigurasi IP Address pada Komputer Penyerang menggunakan IP Address 172.16.1.12 yakni satu network dengan Komputer Server. Selain itu Komputer Penyerang menggunakan IP Default Gateway dan DNS 172.16.1.1 seperti yang dapat dilihat pada Gambar 3. 


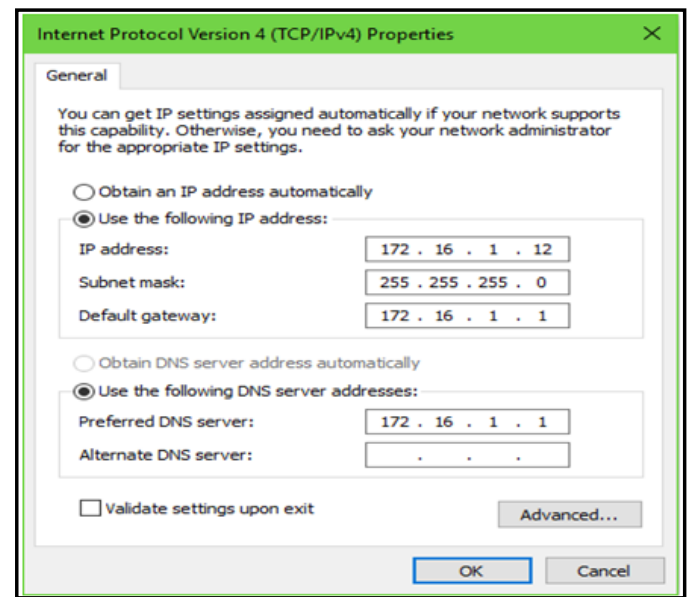

Gambar 3. IP Address Komputer Penyerang

\section{B. Pengujian Sistem}

Apabila semua langkah persiapan selesai dilakukan, selanjutnya beralih ke tahap pengujian masingmasing serangan. Dalam pengujian ini penulis mengujikan serangan yang berupa:

\section{a. PING Attack (ICMP Flooding)}

Untuk pengujian PING Attack dengan cara sebagai berikut:

a) Tambahkan rules pada file myrules.rules untuk memberikan alert apabila ada yang mengirim paket ICMP (PING) ke Komputer Server.

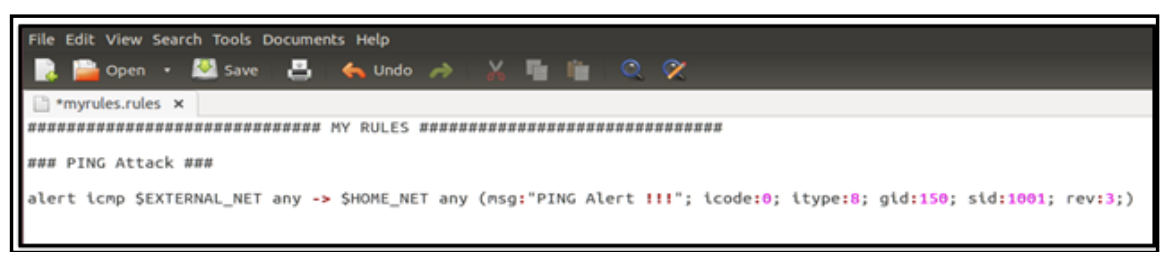

Gambar 4. Rules Snort untuk PING Attack

Rules yang digunakan untuk mendeteksi PING Attack adalah memberikan alert apabila ada ICMP dari \$EXTERNAL_NET ke \$HOME_NET dengan port apapun. Alert ini dikenali dengan pesan "PING Alert !!!" icode:0; dan itype:8; adalah kode dari sebuah aksi PING, gid: 150 berarti Generator ID nya adalah 150 dan sid;1001 berarti Snort Alert ID nya 1001 serta revisi nomor 3.

b) Lakukan PING Attack melalui Komputer Penyerang dengan membuka file PING Attack bat yang ada di Windows sebanyak 25 kali. Lebih jelasnya dapat dilihat pada Gambar 5.

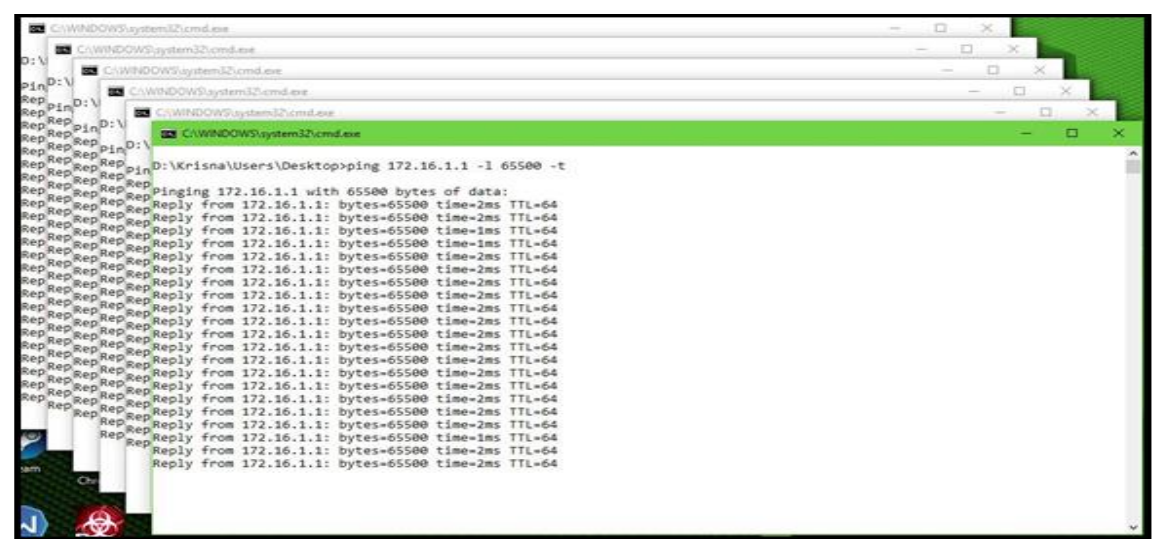

Gambar 5. Ping Attack Terhadap Komputer Sever 
c) Lihat hasil SMS Alert yang dikirim oleh SMS Gateway.

\begin{tabular}{||l||}
\hline \multicolumn{1}{|c|}{$\quad$ Server Snort } \\
172.16.1.12 Melakukan \\
PING Attack ! kepada \\
172.16.1.1 pada \\
2017-01-25 17:54:50 \\
172.16.1.12 Melakukan \\
PING Attack ! kepada \\
172.16.1.1 pada \\
2017-01-25 17:54:40 \\
172.16.1.12 Melakukan \\
PING Attack ! kepada \\
172.16.1.1 pada \\
2017-01-25 17:54:30 \\
\hline
\end{tabular}

Gambar 6. SMS Alert pada Handphone Administrator

Pada Gambar 6 terlihat isi pesan SMS yang diterima oleh Handphone Administrator, waktu yang diperlukan sejak serangan terdeteksi sampai pesan diterima oleh Handphone Administrator adalah 20-30 detik.

d) Amati perbandingan hasil monitoring pengujian (CPU, Memory, Beban Jaringan) sebelum terjadi serangan dan pada saat terjadi serangan.

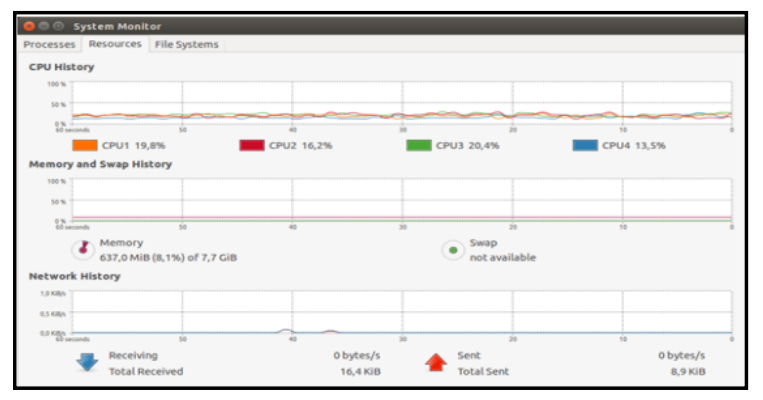

Gambar 7. Hasil Monitoring Sebelum Terjadi PING Attack

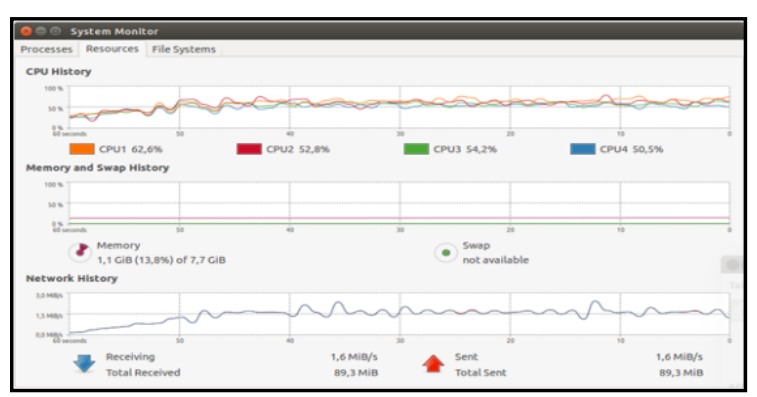

Gambar 8. Hasil Monitoring Pada Saat Terjadi PING

Pada Gambar 7 menunjukkan hasil monitoring sebelum terjadi PING Attack, rata-rata penggunaan CPU adalah 17,5\%, penggunaan RAM sebesar $637 \mathrm{MB}(8,1 \%)$ dan yang terakhir beban jaringan masih 0 bytes/s untuk Sent dan Receivingnya. Sedangkan pada saat terjadi serangan PING Attack, rata-rata penggunaan CPU naik menjadi 54,5\%, penggunaan RAM sebesar 1,1 GB (13.8\%) dan yang terakhir beban jaringan naik untuk Receiving menjadi 1,6 MB/s dan Sent sama yaitu 1,6 MB/s. Untuk lebih detail, dapat dilihat pada Gambar 8. Dari pengujian ini dapat dikatakan bahwa sistem monitoring kemanaan server melalui pemberitahuan SMS berbasis Snort ini berhasil memberikan peringatan berupa SMS Alert ke Handphone Adminstrator apabila terjadi PING Attack. 


\section{b. DoS/DDoS Attack}

Untuk pengujian DoS/DDoS Attack digunakan tool freeware LOIC (Low Orbit Ion Cannon) dengan cara sebagai berikut:

a) Tambahkan rules pada file myrules.rules untuk memberikan alert apabila ada yang melakukan DoS/DDoS Attack ke Komputer Server dengan kriteria alert apabila ada 1000 paket dalam 3 detik ke Komputer Server.

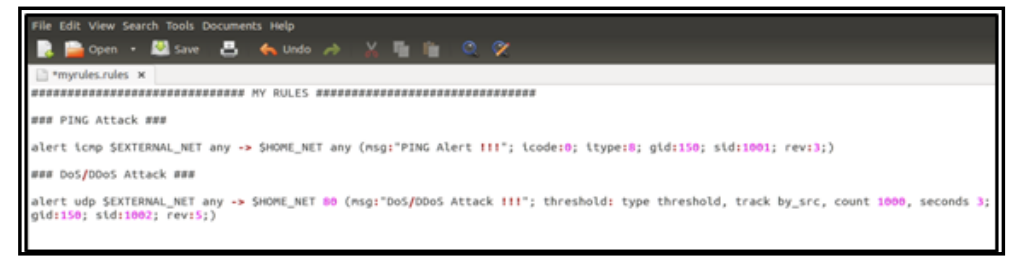

Gambar 9. Rules Snort untuk DoS/DDoS Attack

Pada Gambar 9, rules yang digunakan untuk mendeteksi DoS/DDoS Attack adalah memberikan alert apabila ada UDP dari \$EXTERNAL_NET ke \$HOME_NET dengan port 80. Alert ini dikenali dengan pesan "DoS/DDoS Attack !!!" dengan kriteria alert apabila ada 1000 paket dalam 3 detik berarti sebuah aksi $D o S / D D o S$, gid: 150 berarti Generator ID nya adalah 150 dan sid;1002 berarti Snort Alert ID nya 1002 serta nomor revisi 5.

b) Lakukan DoS/DDoS Attack melalui Komputer Penyerang dengan membuka Program LOIC dan mengatur target serangan yaitu 172.16.1.1 dan mengatur tipe serangan menjadi UDP jumlah threadnya 100 dan jalankan serangan. Untuk tingkat kecepatannya gunakan faster paling kiri. Lebih jelasnya dapat dilihat pada Gambar 10

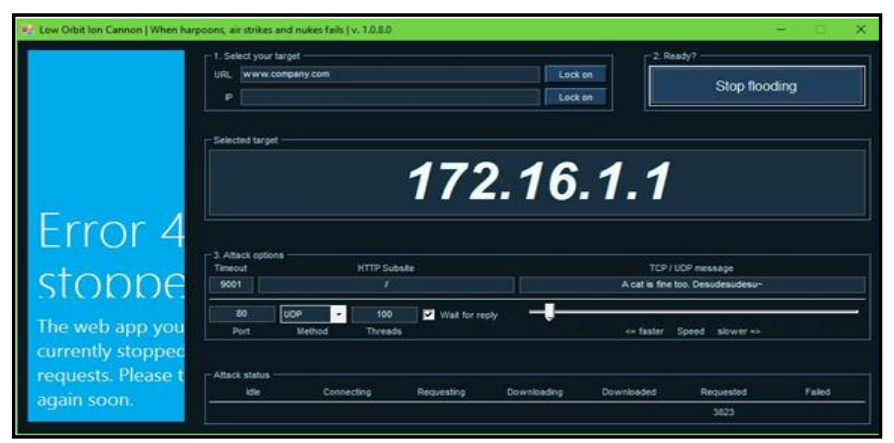

Gambar 10. Aplikasi LOIC Melakukan DoS/DDoS Attack

c) Lihat hasil SMS Alert yang dikirim oleh SMS Gateway.

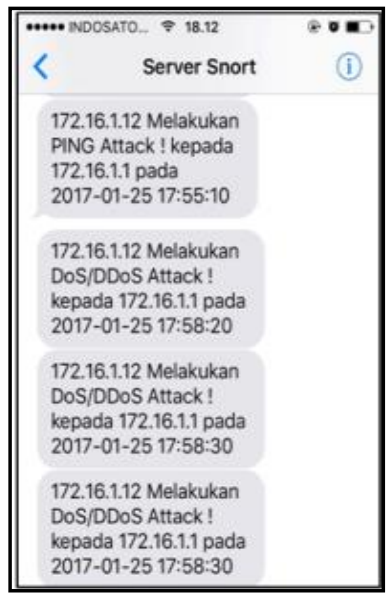

Gambar 11. SMS Alert pada Handphone Administrator 
Pada Gambar 11 isi pesan SMS yang diterima oleh Handphone Administrator terlihat semula ada pesan "172.16.1.12 Melakukan PING Attack ! kepada 172.16.1.1" yakni pesan PING Attack dari pengujian sebelumnya kemudian diikuti dengan pesan "172.16.1.12 Melakukan DoS/DDoS Attack ! kepada 172.16.1.1" secara bertahap. Waktu yang diperlukan sejak serangan terdeteksi sampai pesan diterima oleh Handphone Administrator adalah 20-30 detik.

d) Amati perbandingan hasil monitoring pengujian (CPU, Memory, Beban Jaringan) sebelum terjadi serangan dan pada saat terjadi serangan.

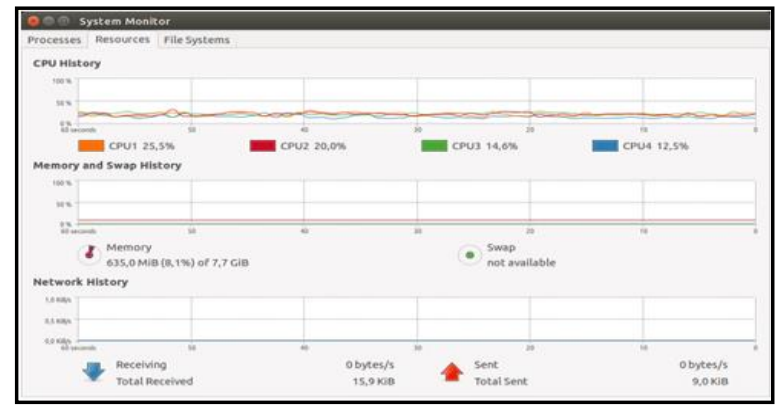

Gambar 12. Hasil Monitoring Sebelum Terjadi DoS/DDoS Attack

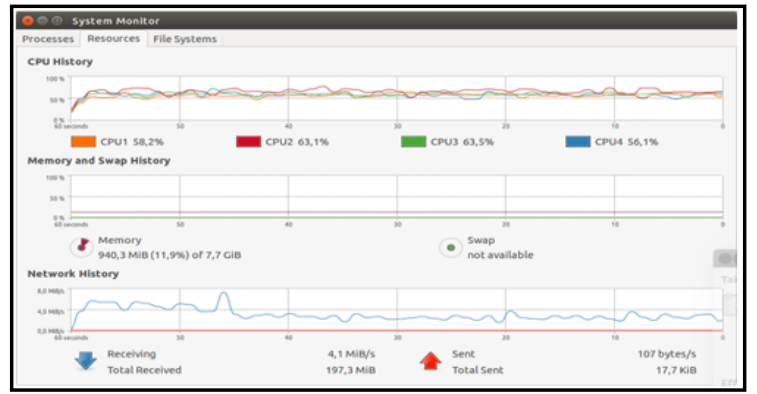

Gambar 13. Hasil Monitoring Pada Saat Terjadi DoS/DDoS Attack

Pada Gambar 12 menunjukkan hasil monitoring parameter sebelum terjadi DoS/DDoS Attack, rata-rata penggunaan CPU adalah 18\%, penggunaan RAM sebesar 635 MB $(8,1 \%)$ dan yang terakhir beban jaringan masih 0 bytes/s untuk Sent dan Receivingnya. Sedangkan pada saat terjadi serangan DoS/DDoS Attack, rata-rata penggunaan CPU naik menjadi 60\%, penggunaan RAM sebesar $940 \mathrm{MB}(11,9 \%)$ dan yang terakhir beban jaringan naik untuk Receiving menjadi 4,1 MB/s dan Sent yaitu 107 bytes. Untuk lebih detailnya dapat dilihat pada Gambar 13. Dari pengujian ini dapat dikatakan bahwa sistem monitoring kemanaan server melalui pemberitahuan SMS berbasis Snort ini berhasil memberikan peringatan berupa SMS Alert ke Handphone Adminstrator apabila terjadi DoS/DDoS Attack.

\section{c. Port Scanning}

Untuk pengujian Port Scanning digunakan tool NMap-ZenMap dengan cara sebagai berikut:

a) Tambahkan rules pada file myrules.rules untuk memberikan alert apabila ada yang melakukan Port Scanning ke Komputer Server.

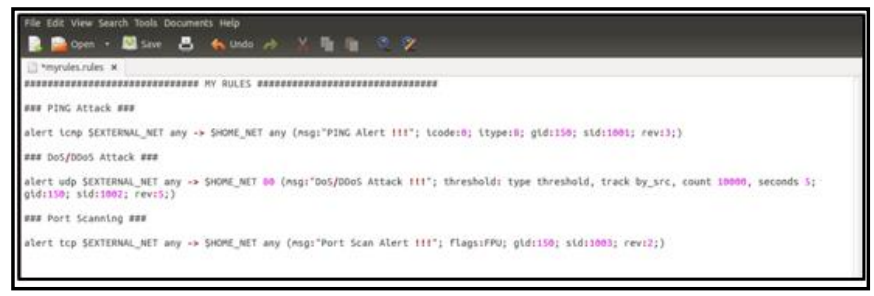

Gambar 14. Rules Snort untuk Port Scanning 
Pada Gambar 14, rules yang digunakan untuk mendeteksi Port Scanning adalah memberikan alert apabila ada TCP dari \$EXTERNAL_NET ke \$HOME_NET dengan port apapun. Alert ini dikenali dengan pesan "Port Scan Alert !!!” flags:FPU adalah flag yang dimiliki oleh nmap, gid: 150 berarti Generator ID nya adalah 150 dan sid;1003 berarti Snort Alert ID nya 1003 serta nomor revisi 2.

b) Lakukan Port Scanning dari Komputer Penyerang dengan membuka Program NMap - ZenMap dan menetapkan target IP menjadi 172.16.1.1 dengan setting profile "Intense scans, All TCP Ports". Apabila sudah siap, klik Start untuk mulai melakukan Port Scanning, proses ini memerlukan waktu sekitar satu menit. Untuk lebih jelasnya dapat dilihat pada Gambar 15.

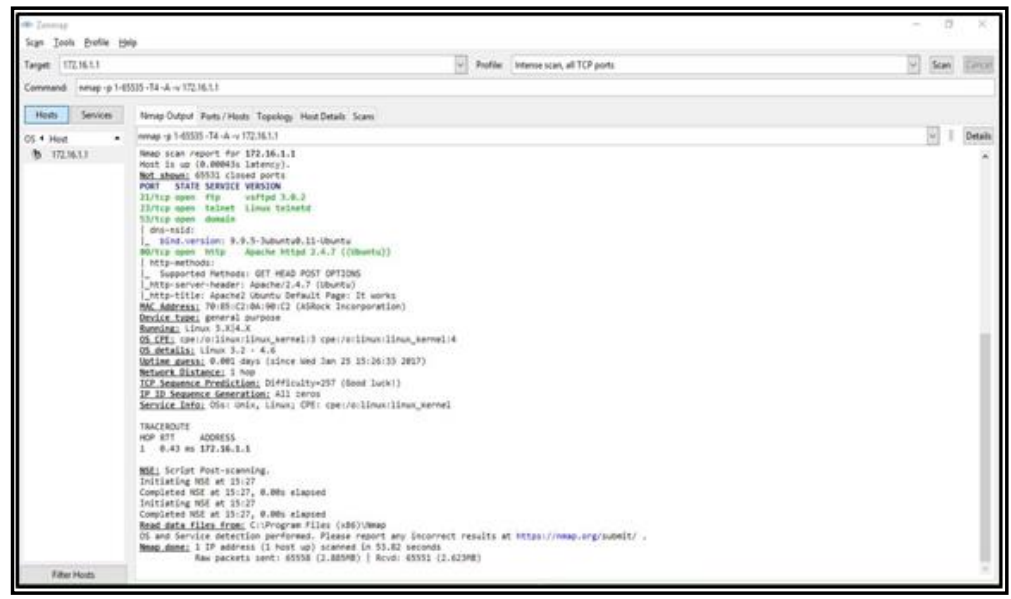

Gambar 15. Aplikasi Zenmap melakukan Port Scanning

c) Lihat hasil SMS Alert yang dikirim oleh SMS Gateway.

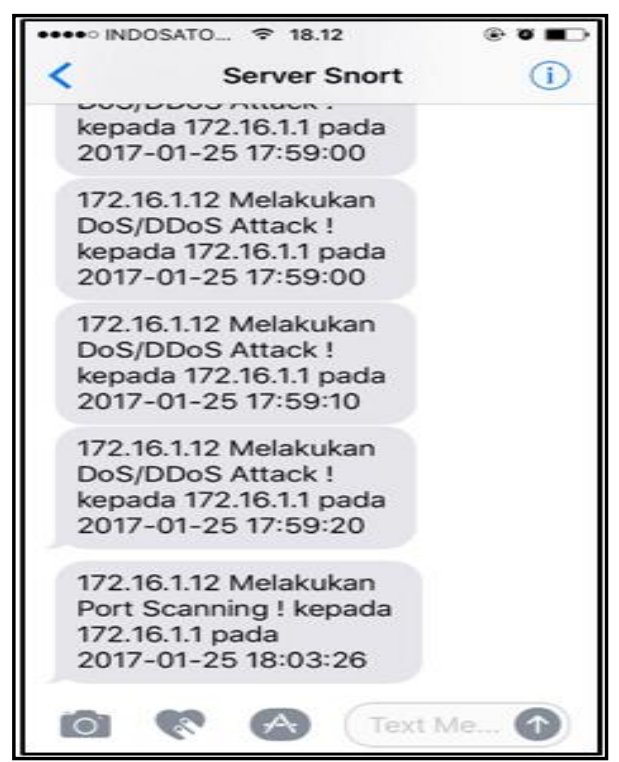

Gambar 16. SMS Alert pada Handphone

Pada Gambar 16 isi pesan SMS yang diterima oleh Handphone Administrator terlihat semula ada pesan "172.16.1.12 Melakukan DoS/DDoS Attack ! kepada 172.16.1.1” yakni pesan DoS Attack dari pengujian sebelumnya kemudian diikuti dengan pesan "172.16.1.12 Melakukan Port Scanning ! kepada 172.16.1.1". Waktu yang diperlukan sejak serangan terdeteksi sampai pesan diterima oleh Handphone Administrator adalah 20-30 detik. 
d) Amati perbandingan hasil monitoring pengujian (CPU, Memory, Beban Jaringan) sebelum terjadi serangan dan pada saat terjadi serangan.

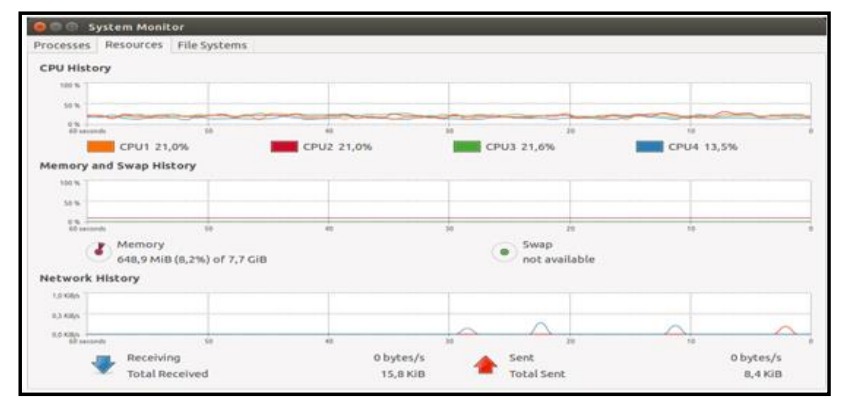

Gambar 17. Hasil Monitoring Sebelum Terjadi Port Scanning

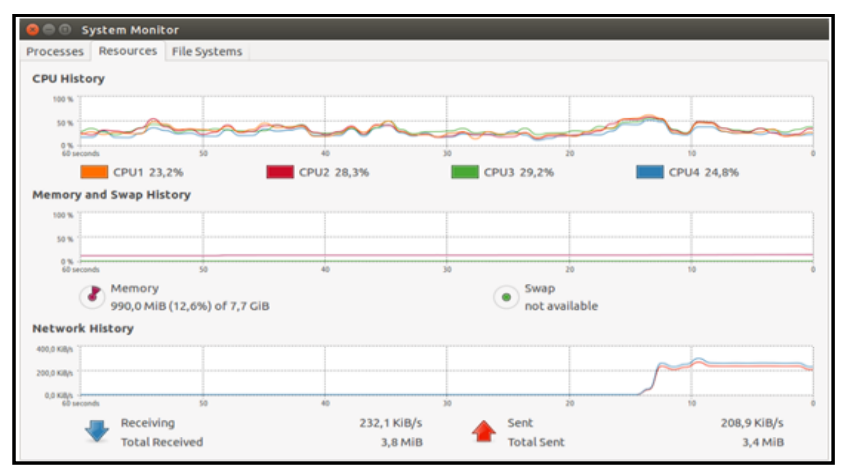

Gambar 18. Hasil Monitoring Pada Saat Terjadi Port Scanning

Pada Gambar 17 menunjukkan hasil monitoring sebelum terjadi Port Scanning, rata-rata penggunaan CPU adalah 19\%, penggunaan RAM sebesar 648 MB $(8,2 \%)$ dan yang terakhir beban jaringan masih 0 bytes/s untuk Sent dan Receivingnya. Sedangkan pada saat terjadi serangan Port Scanning, rata-rata penggunaan CPU naik menjadi 26\%, penggunaan RAM sebesar 990 MB (12,6\%) dan yang terakhir beban jaringan naik untuk Receiving menjadi $232 \mathrm{~KB} / \mathrm{s}$ dan Sent sama yaitu 208 KB/s. Untuk lebih detailnya dapat dilihat pada Gambar 18. Dari pengujian ini dapat dikatakan bahwa sistem monitoring kemanaan server melalui pemberitahuan SMS berbasis Snort ini berhasil memberikan peringatan berupa SMS Alert ke Handphone Adminstrator apabila terjadi Port Scanning

\section{d. Telnet Access}

Untuk pengujian Telnet Akses tools yang digunakan adalah Command prompt yang tersedia pada Windows, dengan cara sebagai berikut:

a) Tambahkan rules pada file myrules.rules untuk memberikan alert apabila ada yang mengakses server via Telnet.

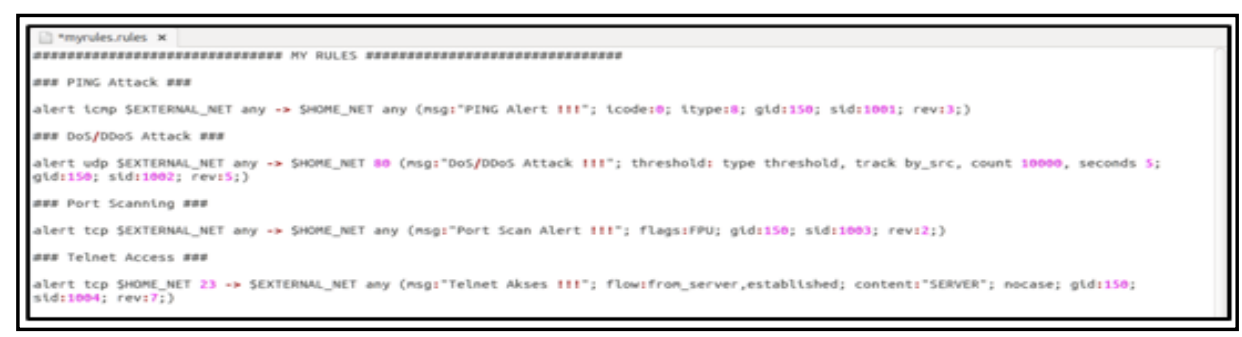

Gambar 19. Rules Snort untuk Telnet Access

Pada Gambar 19, rules yang digunakan untuk mendeteksi Telnet Access adalah memberikan alert apabila ada TCP dari \$HOME_NET dengan port 23 ke \$EXTERNAL_NET. Alert ini dikenali dengan pesan "Telnet Access !!!" flow: from_server adalah aliran data berasal dari Server, content: 
SERVER adalah isi konten yang dikirim, gid: 150 berarti Generator ID nya adalah 150 dan sid;1004 berarti Snort Alert ID nya 1004 serta nomor revisi 7.

b) Lakukan Telnet akses dari Komputer Penyerang dengan membuka Program Command prompt dan mengakses server dengan telnet 172.16.1.1 seperti pada gamabr 20.

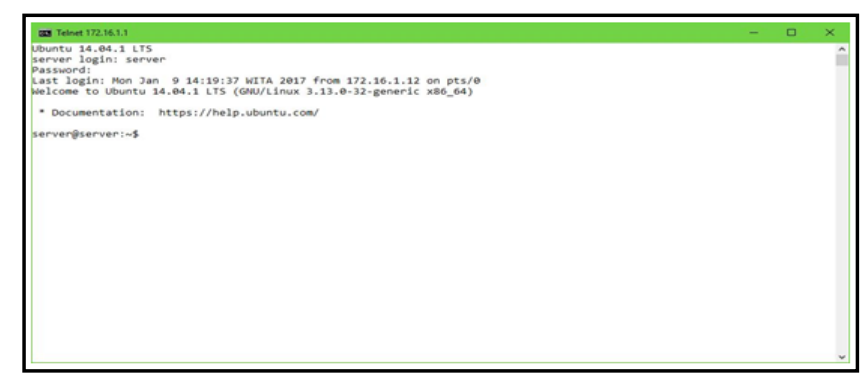

Gambar 20. Tools Command Prompt melakukan Telnet Access

c) Lihat hasil SMS Alert yang dikirim oleh SMS Gateway.

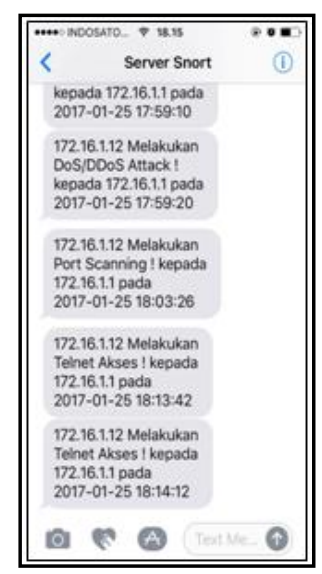

Gambar 21. SMS Alert pada Handphone Administrator

Pada Gambar 21 isi pesan SMS yang diterima oleh Handphone Administrator terlihat semula ada pesan "172.16.1.12 Melakukan Port Scanning! kepada 172.16.1.1" yakni pesan Port Scanning dari pengujian sebelumnya kemudian diikuti dengan dua pesan "172.16.1.12 Melakukan Telnet Akses ! kepada 172.16.1.1". Waktu yang diperlukan sejak serangan terdeteksi sampai pesan diterima oleh Handphone Administrator adalah 20-30 detik.

d) Amati perbandingan hasil monitoring pengujian (CPU, Memory, Beban Jaringan) sebelum terjadi serangan dan pada saat terjadi serangan.

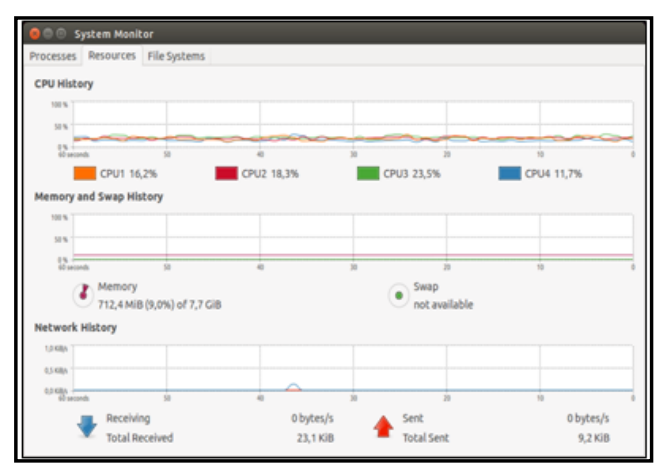

Gambar 22. Hasil Monitoring Sebelum Terjadi Telnet Access 


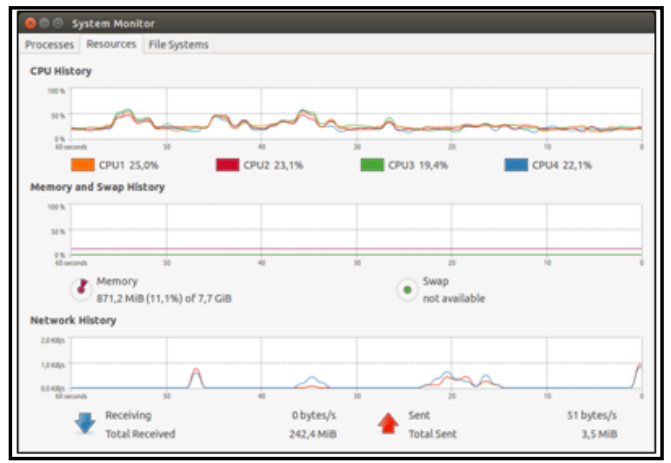

Gambar 23. Hasil Monitoring Pada Saat Terjadi Telnet Access

Pada Gambar 23 menunjukkan hasil monitoring parameter sebelum terjadi Telnet Akses, rata-rata penggunaan CPU adalah 15\%, penggunaan RAM sebesar 712 MB $(9,0 \%)$ dan yang terakhir beban jaringan masih 0 bytes/s untuk Sent dan Receivingnya. Sedangkan pada saat terjadi Telnet Access, rata-rata penggunaan CPU naik menjadi 22,5\%, penggunaan RAM sebesar 871 MB $(11,1 \%)$ dan yang terakhir beban jaringan tetap sama untuk Receiving yaitu 0 bytes/s dan Sent naik menjadi 51 bytes. Terlihat tidak ada perubahan yang signifikan terhadap penggunaan sumber daya pada saat terjadi Telnet Access. Hal ini dikarenakan telnet akses tidak bertujuan untuk melumpuhkan server secara langsung, namun untuk mendapatkan akses kendali server. Dari pengujian ini dapat dikatakan bahwa sistem monitoring kemanaan server melalui pemberitahuan SMS berbasis Snort ini berhasil memberikan peringatan berupa SMS Alert ke Handphone Adminstrator apabila terjadi Telnet Akses.

\section{e. FTP Access (File Transfer Potocol)}

Untuk pengujian FTP Akses tools yang digunakan adalah Command prompt yang tersedia pada Windows, dengan cara sebagai berikut:

a) Tambahkan rules pada file myrules.rules untuk memberikan alert apabila ada yang mengakses FTP Server.

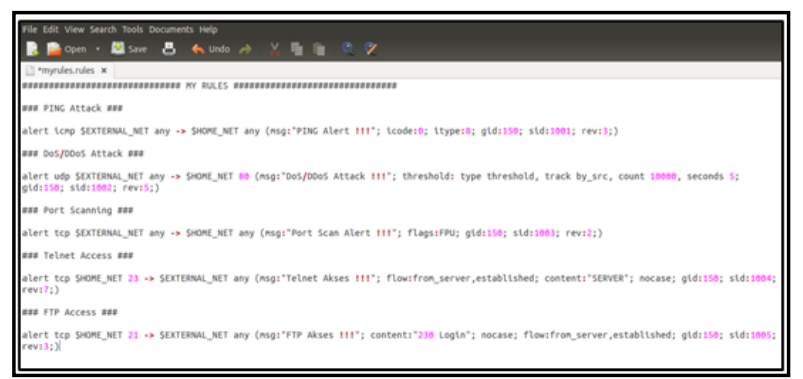

Gambar 24. Rules Snort untuk FTP Access

Pada Gambar 24, rules yang digunakan untuk mendeteksi FTP Access adalah memberikan alert apabila ada TCP dari \$HOME_NET dengan port 21 ke \$EXTERNAL_NET. Alert ini dikenali dengan pesan "FTP Access !!!" flow: from_server adalah aliran data berasal dari Server, content: 230 login adalah isi konten yang dikirim, gid: 150 berarti Generator ID nya adalah 150 dan sid;1005 berarti Snort Alert ID nya 1005 serta nomor revisi 3.

b) Lakukan FTP akses dari Komputer Penyerang dengan membuka Program Command prompt dan mengakses server dengan ftp 172.16.1.1. 


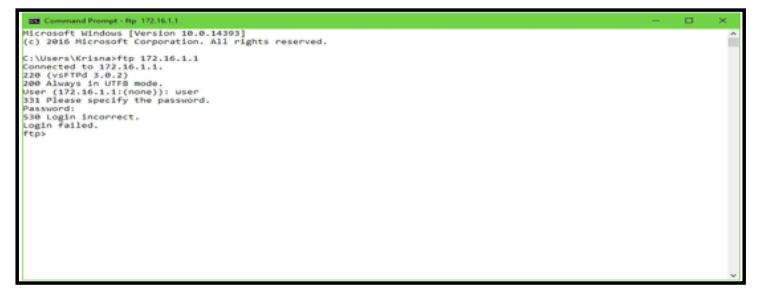

Gambar 25. Tools Command Prompt melakukan FTP Access

c) Lihat hasil SMS Alert yang dikirim oleh SMS Gateway.

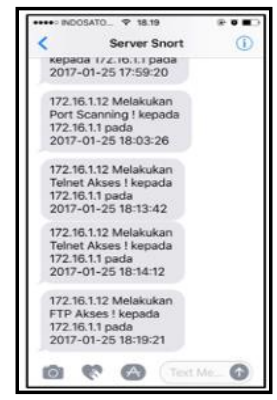

Gambar 26. SMS Alert pada Handphone

Pada Gambar 26 isi pesan SMS yang diterima oleh Handphone Administrator terlihat semula ada pesan "172.16.1.12 Melakukan Telnet Akses ! kepada 172.16.1.1" yakni pesan Telnet Akses dari pengujian sebelumnya kemudian diikuti dengan pesan "172.16.1.12 Melakukan FTP Akses ! kepada 172.16.1.1". Waktu yang diperlukan sejak serangan terdeteksi sampai pesan diterima oleh Handphone Administrator adalah 20-30 detik.

d) Amati perbandingan hasil monitoring pengujian (CPU, Memory, Beban Jaringan) sebelum terjadi serangan dan pada saat terjadi serangan.

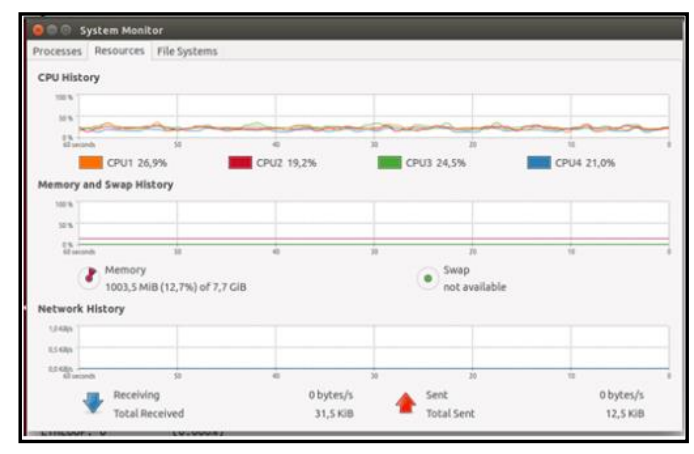

Gambar 27. Hasil Monitoring Sebelum Terjadi FTP Access

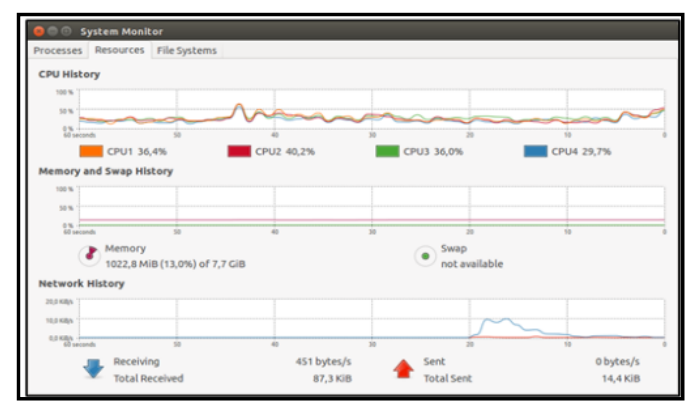

Gambar 28. Hasil Monitoring Pada Saat Terjadi FTP Access 
Terlihat tidak ada perubahan yang signifikan terhadap penggunaan sumber daya pada saat terjadi FTP Access. Hal ini dikarenakan telnet akses tidak bertujuan untuk melumpuhkan server secara langsung, namun untuk mendapatkan akses file di server. Untuk lebih jelasnya dapat dilihat pada Gambar 28. Dari pengujian ini dapat dikatakan bahwa sistem monitoring kemanaan server melalui pemberitahuan SMS berbasis Snort ini berhasil memberikan peringatan berupa SMS Alert ke Handphone Adminstrator apabila terjadi FTP Akses.

\section{PENUTUP}

Berdasarkan pengujian dan pembahasan yang telah dilakukan maka dapat diambil kesimpulan terhadap sistem monitoring kemanaan server melalui pemberitahuan SMS berbasis Snort sebagai berikut:

1) Sistem monitoring kemanaan server yang diterapkan, menggukanan Snort sebagai mesin pendeteksi utama, Barnyard2 sebagai pembaca hasil dari keluaran Snort dan menyimpannya ke dalam database, BASE sebagai tampilan database dalam bentuk web, serta Gammu sebagai SMS Gateway untuk mengirim alert ke Handphone Administrator.

2) Sistem monitoring kemanaan server yang diterapkan telah berhasil dibangun dan diujikan. Secara keseluruhan, sistem ini dapat bekerja dengan baik sebagai pemberi peringatan dini adanya upaya serangan terhadap server.

3) Dari hasil pengujian masing-masing serangan, dapat dilihat pada saat terjadi serangan, penggunaan sumber daya untuk serangan PING Attack, DoS/DDoS Attack dan Port Scanning meningkat dalam hal penggunaan CPU, Memory dan Beban Jaringan. Namun untuk Telnet dan FTP Akses terlihat tidak ada perubahan yang signifikan terhadap penggunaan CPU, Memory dan Beban Jaringan.

\section{Daftar Pustaka}

Desnanjaya, I. G. M. N., Iswara, I. B. A. I., Ekayana, A. A. G., Santika, P. P., \& Hartawan, I. N. B. (2020). Automatic high speed photography based microcontroller. Journal of Physics: Conference Series. https://doi.org/10.1088/1742-6596/1469/1/012096

Ekayana, A. A. G., Hartawan, I. N. B., Desnanjaya, I. G. M. N., \& Joni, I. D. M. A. B. (2020). Body mass index measurement system as a desktop-based nutrition monitor. J. Phys. Ser., 1469.

Hartawan, I. N. B., \& Iswara, I. B. A. I. (2015). Analisis Penerapan AoE dan LVM sebagai Teknologi Berbagi Media Penyimpanan pada Multi Server. S@CIES. https://doi.org/10.31598/sacies.v5i2.61

Hartawan, I. N. B., \& Satwika, I. K. S. (2016). Rancang Bangun Laboratorium Virtual Berbasis Cloud Computing Di Stmik Stikom Indonesia. S@CIES. https://doi.org/10.31598/sacies.v7i1.117

Hartawan, I. N. B., \& Sudiarsa, I. W. (2019). ANALISIS KINERJA INTERNET OF THINGS BERBASIS FIREBASE REAL-TIME DATABASE. Jurnal RESISTOR (Rekayasa Sistem Komputer). https://doi.org/10.31598/jurnalresistor.v2i1.371

Rehman, R. U. (2003). Intrusion Detection Systems with Snort. New Jersey: Prentice Hall.

Tarigan, D. E. (2012). Membangun SMS Gateway Berbasis Web dengan Codelgniter. Jakarta: Lokomedia. 